\title{
Allocative and Technical Efficiency Analysis of Cassava Farming in Bitefa Village, East Miofamo District, Middle North Timor
}

\author{
Abdul Wahib Muhaimin* \\ Department of Socio Economics, Faculty of Agriculture, Brawijaya University, Jl. Veteran, \\ Malang 65145, Indonesia
}

Received: 2 July 2015; Revised: 12 October 2017; Accepted: 1 December 2017

\begin{abstract}
Cassava is a food crop with great economic value since its cost is affordable and has been passed down to the generation. People at Bitefa village are majority a farmer who depends their life on agriculture to meet the needs. Problems faced by farmers in farming cassava at Bitefa village are farming management that is not in accordance with the guidelines and the use of factors of production that is not suitable for the dose recommended. This suggests that the use of factors of production are not efficient. Research objectives are: (1) to analyze the factors that affect the production of cassava, (2) to analyze the level of allocative and technical efficiency, (3) to analyze factors that affect technical inefficiency. The efficient use of factors of production is expected to increase production and income for farmers of cassava. The result obtained using stochastic frontier production function analysis is that the influence of cassava farming real production is the production of land and seeds. Meanwhile, labor, cost factors and the use of manure have no effect on the real production of cassava. The technical efficiency level of cassava farming in the research area is the lowest by 0.80 of which amounted to 0.99 . While the level of NPMxPx for land use allocative efficiency is 1 so that the allocation of land use in the area of research has not been efficient. NPMxPx for the use of seed allocation is 1 so that the use of seedlings is also not efficient. Nonformal education influence is real and marked positive effect against inefficiency. Formal education is marked negative but having a real effect against the inefficiency. Farmer's age is marked negative and not real, while the experience and the number of family members are marked positive but having no real effect on the production of cassava.
\end{abstract}

Keywords: production factors; stochastic frontier; efficiency; Marginal Product Value

\section{How to cite:}

Muhaimin, A. W. (2017). Allocative and Technical Efficiency Analysis of Cassava Farming in Bitefa Village , East Miofamo District , Middle North Timor. HABITAT, 28(3), 75-82. https://doi.org/10.21776/ub.habitat.2017.028.3.11

\section{Introduction}

The realization of sustainable and improved as well as local-based resources agriculture industry to enhance food independence, added value, export and farmers welfare is the vision of agricultural development. One of the programs of agricultural development is production increase, productivity, and food crop quality to achieve self-sufficiency and sustainable selfsufficiency (Laporan Kinerja Kementrian Pertanian, 2011).

Food crop contains protein and carbohydrate for human needs, one of them is

*Correspondence Author:

E-mail: abdulwahib@yahoo.com cassava. Cassava is categorized a strategic commodity as it influences other food crop commodities' price and has a bright prospect (Montagnac, Davis, \& Tanumihardjo, 2009). In addition, cassava is also substitution of rice and corn.

One of districts in East Nusa Tenggara (NTT) having a larger area of dryland than wetland is North Middle Timor (TTU). It borders with Oekusi district of The Democratic Republic of Timor-Leste (RDTL) and its area is 187,650 ha of dryland and 11,401 Ha wetland (Central Statistic Agency or BPS of TTU, 2013). District in TTU becoming the center of cassava production is East Miomafo subdistrict. It produces cassava by 6,818 ton/ha of an area of $1,322 \mathrm{Ha}$ and the result of production by 9,014 ton. For that matter, if compared nationally, 
cassava productivity in TTU, especially at East Miomafo subdistrict, is far from the average value, which is 9.5 tons/ha. In accordance with the problem above, cassava production increase depends on the factors usage that should be efficient and effective. The usage of production factors is said effective if the farmer can allocate the resources owned well and in addition, it is categorized efficiently if resources utilization results in an output that is bigger than input (Soekartawi, 2002).

In this research, one of the villages representing East Miomafo subdistrict is Bitefa. It is chosen as it has highest land area and cassava production of all villages in East Miomafo subdistrict, the harvested area is 253 ha and the production is $1,518,000 \mathrm{~kg}$, as such the productivity gained is 6 ton/ha. According to the data, it is obvious that there is a gap between harvested area and production resulted.

The data of cassava production in Bitefa village of east Miomafo subdistrict is still under the standard. The highest cassava production at East Miomafo subdistrict in 2012 is held by Bitefa village with 253 ha of harvested area and $1,518,000 \mathrm{~kg}$ production, as such the production gained is 6 ton/ha. This means that there is a gap between the harvested area that must be undertaken and production resulted.

Therefore, cassava productivity and production at Bitefa village of East Miomafo subdistrict is still able to be improved. The efficiency of production factors usage truly influences production resulted and income earned by the farmer. Problems faced by cassava farmers at Bitefa village of East Miomafo subdistrict are: (1) the area of business land that is not economic yet, (2) technology implied by the farmer is still simple, (3) limited capital owned by a farmer, (4) unpredictable climate and weather.

The problem of input usage that is not optimum as illustrated above, together with an external factor like climate and weather and insect attack as well as disease beyond the farmer's control, causes cassava farming in Bitefa village of East Miomafo subdistrict is not performed optimally and efficiently.

The objectives of this research are to:

a. Analyze factors influencing cassava production at Bitefa village of East Miomafo subdistrict.

b. Analyze allocative and technical efficiency level of cassava farming at Bitefa village of East Miomafo subdistrict. c. Analyze factors influencing the technical efficiency of cassava farming at Bitefa village of East Miomafo subdistrict.

\section{Methodology}

\subsection{Sample Collection Methods}

The previous survey collects that the number of population at Bitefa village is 460 cassava farmers. This sample is determined by Simple Random Sampling using Slovin formula in Kuncoro (2001);

$\mathrm{n}=\frac{\mathrm{N}}{1+\mathrm{N}(\alpha)^{2}}$

At which;

$\mathrm{n}=$ Sample size

$\mathrm{N}$ = Population size

$\alpha=$ error

According to the formulation above, this research used $12 \%$ of the population so that the sample is 60.33 farmers from 460 people that was then made to the 60 farmers.

\subsection{Data analysis methods.}

a. Production Function Analysis of Stochastic Frontier

Analysis methods used to answer the first purpose of factors influencing cassava farming is stochastic frontier production function. Estimator equation model of frontier production function of cassava function can be written as follow.

$$
\begin{aligned}
& \operatorname{Ln} Y=\beta_{0}+\beta_{1} \ln X_{1}+\beta_{2} \ln X_{2}+\beta_{3} \ln X_{3}+\beta_{4} \ln \\
& X_{4}+\beta_{5} \ln X_{5}+v_{i}-u_{i} \\
& \text {..................................... (2) }
\end{aligned}
$$

At which :

$\mathrm{Y}=$ cassava production total $(\mathrm{kg})$

$\beta 0=$ constant

$\beta \mathrm{i}=$ production elasticity of cassava production factor at-i

$\mathrm{X} 1 \mathrm{l}=$ land usage (ha)

$\mathrm{X} 2=$ seeds usage $(\mathrm{kg})$

$\mathrm{X} 3$ = labor usage $(\mathrm{HOK})$

$\mathrm{X} 4=$ cost usage $(\mathrm{Rp})$

$\mathrm{X} 5=$ animal manure usage $(\mathrm{kg})$

$\mathrm{vi}=$ asymmetric, normally distributed random error

ui $=$ one-sided error term $(u i \geq 0)$ or technical inefficiency effect

Stochastic frontier parameter assessment and technical efficiency were done using Maximum Likelihood estimation (MLE). MLE 
is a parameter jointly with both restricted and non-restricted used to show residual level achieved in a model and efficiency or inefficiency of OLS methods. The general equation of MLE is written as:

$\mathrm{Y}_{\mathrm{i}}=\beta_{0}+\beta_{1} \mathrm{X}_{1}+\mathrm{u}_{1}{ }^{\prime}+\mathrm{v}_{1}$

The residual indicates technical inefficient error term value. On the frontier model of MLE approaches, output resulted indicates gamma square value that is product variation value gained by production efficiency. This model also assumes that residual achievement got indicates value as minimum as possible and states that this model will be more significant than OLS (Coelli, 1998).

b. Technical Efficiency Analysis of Cassava Farming

Quantitative analysis was used to answer the second aim which is to know technical efficiency level. The technical efficiency level of cassava farming is categorized into several groups and then called technical efficiency index, it illustrates the difference of technical efficiency level achieved by different cassava farming. Cassava farming efficiency or inefficiency in Bitefa village of East Miomafo subdistrict is supposed to use mathematics equivalent like this:

$T E_{1}=\frac{Y i}{Y i *}$

At which :

$\mathrm{TEi}=$ Technical efficiency achieved by observation at-i

$\mathrm{Yi}=$ Actual output of cassava farming $(\mathrm{kg} / \mathrm{ha})$

$\mathrm{Yi}^{*}=$ Potential output of cassava farming $(\mathrm{kg} / \mathrm{ha})$

TEi is a farming technical efficiency at-i, which is $0<\mathrm{TEi}<1$. Technical efficiency value is the opposite of technical inefficiency effect value and is only used to the function having cross-section data.

c. Allocative Efficiency Analysis of Cassava farming

Cassava farming can be said efficient if the Marginal Product Value (NPM) of a production is as same as the price (Makeham, 1990). In order to know allocative efficiency level of farming is indicated by NPMxi ratio value with Pxi from each factor of production.

$\mathrm{Ep}=\frac{\mathrm{dy} / \mathrm{y}}{\mathrm{dx} / \mathrm{x}}=\frac{\mathrm{dy} \cdot \mathrm{x}}{\mathrm{dx} \cdot \mathrm{y}}=\frac{\mathrm{PM}(\text { Produk Marginal })}{\mathrm{PR}(\text { Produk rata-rata) }} \ldots$

$\pi=\mathrm{TR}-\mathrm{TC}$

$\pi$ max tercapai during $\pi^{\prime}=0$ $\frac{\mathrm{dy} \cdot \mathrm{Py}}{\mathrm{dx}}=\mathrm{Px}$

MPP. Py $=$ Px

$\mathrm{NMPx}=\mathrm{Px}$,

therefore,

$\frac{\mathrm{NPMxi}}{\mathrm{Pxi}}=1$

At which:

NPMxi = marginal product value $(\mathrm{Rp})$

Py $\quad=$ product price per unit $(\mathrm{Rp})$

Epi = product elasticity at $-\mathrm{i}$

$\mathrm{Y}=$ production $(\mathrm{kg})$

$\mathrm{Xi}=$ production factor at $\mathrm{i}$

\section{Results and Discussion}

\subsection{Analysis of factors influencing cassava production}

Stochatic Frontier Approached used to analyze factors influencing cassava production is Maximum Likelihood Estimation (MLE) approaches, following is the influence of production factors:

a. Land Area (X1)

Table 1. Estimation Result of Production Function Parameter of Cassava Farming Frontier Stochastic at Biteva village 2013. with MLE approaches

\begin{tabular}{lccc}
\hline \multicolumn{1}{c}{ Variable } & Coefficient & $\begin{array}{c}\text { Standard } \\
\text { error }\end{array}$ & t-ratio \\
\hline Intercept & 1.788 & 0.964 & 1.853 \\
\hline Land Area (X1) & 3.299 & 0.694 & $4,751^{* * *}$ \\
\hline Seed (X2) & -2.266 & 0.672 & $-3,369^{* * *}$ \\
\hline TK (X3) & 0.186 & 0.184 & 1.009 \\
\hline Cost (X4) & -0.454 & 0.421 & -1.080 \\
\hline Seed (X5) & 0.158 & 0.140 & 1.130 \\
\hline sigma-squared & 7.592 & 5.633 & 1.347 \\
\hline Gamma & 0.999 & 0.000 & 0.000 \\
\hline $\begin{array}{l}\text { log likelihood } \\
\text { function }\end{array}$ & & -75.579 & \\
\hline $\begin{array}{l}\text { LR test of the } \\
\text { one-sided error }\end{array}$ & & 89.692 & \\
\hline $\begin{array}{l}\text { Descipt } \\
\end{array}$
\end{tabular}

Description

$\begin{array}{ll}* * * & =\text { significant at } \alpha 1 \%(2,687) \\ * * & =\text { significant at } \alpha 5 \%(2.021) \\ * & =\text { significant at } \alpha 10 \%(1.678)\end{array}$

According to Table 1., it is known that the land has a positive coefficient by 3,299 with $\mathrm{t}$ count of 4,751, in addition, $t$ count value is 
higher than $t$ table by 2,687 . This indicates that the variable of land area has a significant influence on the cassava production with error level by $0.1 \%$ or trust level by $99.9 \%$. This result correlates with the hypothesis that land area factor has a positive influence and direct relationship with production, it means with only $1 \%$ additional land will increase production by $3,299 \%$.

The influence of land area positively is caused by the real condition at a field where the farmers follow the program of Food Labor Intensive in North Middle Timor District. This program obligates farmer of the rice-for-the poor (Raskin) receiver to have a 25 are produced land at every stage of RASKIN acceptance. This causes the land area owned by the farmer is wider than at the end can increase cassava production.

\section{b. $\quad$ Seed (X2)}

The coefficient of seeds is negative which is $-2,266$ and $t$ count value is $-3,369$. It concludes that $\mathrm{t}$ count is higher than $\mathrm{t}$ table at the level of $1 \%(2,687)$; as a result, the seed has significant influence over the cassava production in the research area. This is in accordance with the hypothesis that seed has a negative influence on the production. This means that the changer has an indirect relationship with production so that it can be said that seed gives a negative influence over the production of cassava where seed additional can decrease production.

The negative influence of seed is caused by the one used by a farmer does not have any licenses or not an improved one, the seed used is the local seed that has more than three or four times its generation.

The reason why farmer more chooses local seed than the licensed is due to it has been believed that the local seed is more resistant to the insect attack. Therefore, the usage of licensed or improved seed or by farmer tends to be able to increase cassava production in the research area.

\section{c. Labour (X3)}

The coefficient value of labor variable is negative by 0,186 and $t$ count value is 1,009 . According to this matter, $\mathrm{t}$ count value is smaller than $t$ table at the level of $1 \%(2,687), 5 \%(2,021)$ and $10 \%(1,678)$, thus, labour factor has a positive influence but not significant to the cassava production in the research area, this means not accordance with the hypothesis that labour factor has a negative influence on the production. This indicates the more the labor used in cassava farming, the more increase production resulted. This variable has a positive coefficient meaning that this changer has a direct relationship with production so that it can be said that labor factor gives a positive influence over the cassava production.

The result having positive but not significant influence over the labor variable is caused by the real condition in the research area where the labor used is the family of the cassava farmers themselves. Not active enough but with a high number involvement causes ineffective and inefficiency in conducting the farming activity.

\section{d. $\quad$ Cost (X4)}

The coefficient value of cost variable is negative by -0.454 and $t$ count value by -1.080 . According to this problem, $t$ count value is smaller than $t$ table at the level of $1 \%(2,704), 5 \%$ $(2,021)$ and $10 \%(1,678)$, thus, the factor of cost has a negative but not significant influence over the cassava production in the research area, this means that it is not accordance with the hypothesis that cost has a positive influence on the production. This variable has a negative coefficient which means that this changer has an indirect relationship with production so that it can be said that the factor of cost has a negative influence on the cassava production.

Either having a negative or not significant influence of cost variable is caused by the real condition in the research area where fund allocated by the farmer is relatively small. This is caused there is no cost for land rent and seed purchase, land used for cassava farming is farmer's own land and the seed used is derived seed of harvest results. Expenditures allocated by farmers are farming cost and tax. In addition, the small cost allocated by the farmer is caused by farmers' ability in capital and cost provision of farming is limited.

\section{e. Animal Manure (X5)}

The coefficient value of animal manure variable is positive by 0.158 and $t$ count value is 1.130. Therefore, $\mathrm{t}$ count value is smaller than $\mathrm{t}$ table at the level of $1 \%(2,704), 5 \%(2,021)$ and $10 \%(1,678)$, as a result, the factor of animal manure has a positive but not significant influence over the cassava farming in the research area. This variable has a positive coefficient which means this changer has a direct relationship with production so that it can be said 
that this is in accordance with the hypothesis that animal manure factor has a positive influence over the production.

Having no significant influence of animal manure usage over the cassava production is due to the real condition at which the availability of TSP, NPK, and KCL fertilizer is still low as the location of fertilizer provision and farmland is far away so complicating farmer to get it. This is accompanied by farmer's knowledge and skill in applying fertilizer is still low. Moreover, fertilizer application in a mannered way, which is through a technic, type, and dose that is in accordance with plant's needs is an indicator of farmer's success. (Barber., \& Benedito de Barber. 1980). This matter states that if the farmer can apply fertilizer in a recommended dose can increase cassava production.

\section{f. Sigma-Square, Gamma}

The value of sigma-square $(\sigma)$ and gamma $(\gamma)$ gained from estimation using MLE methods is 7.59 and 0.99. This result indicates that the sigma-square $(\sigma)$ higher than zero is influenced by technical inefficiency in a model of the production function. Gamma value $(\gamma)$ by 0.99 indicates that the error caused by technical inefficiency component by $99 \%$ means that the difference between the real production and the maximum product is more caused by technical inefficiency effect, while the remaining is caused by random error variable or variable beyond the model built like weather and insect attack.

In order to know whether all cassava farmers have achieved or not technical efficiency to conduct farming, it can be known using Likelihood Ratio Test (LR). Hypothesis test conducted in this research is using assumption result of Likelihood Ratio Test (LR) with help software frontier 4.1. LR test value in frontier result using MLE method is 89.69. LR score result was then compared with critical value with 1 restriction total and error level of $5 \%$ is 2.71 . After being compared, the result of LR test is higher than the critical value. This indicates that coefficient of each variable in an inefficiency effect model is not same as zero. Therefore, each of modifying variable in inefficiency effect model influences inefficiency level in the production process of cassava farming. This reveals that frontier production function is able to explain the existing data on the phenomenon of the technical inefficiency of cassava farming. It means that cassava farmer in the research area is not fully efficient in performing their farming.

\subsection{Analysis of allocative and technical efficiency of cassava farming}

a. Technical Efficiency Analysis of Cassava Farming

Technical Efficiency Analysis of cassava farming aims to know the highest and the lowest efficiency as well as the average efficiency achieved by the farmer in running cassava farming in Bitefa village. The level of efficiency achieved by respondents in the research area can be seen in Table 2 .

Table 2. Efficiency Frequency Distribution of Cassava Farming Technical in Biteva Village 2013

\begin{tabular}{lccr}
\hline No. & $\begin{array}{c}\text { Efficiency } \\
\text { Level }\end{array}$ & $\begin{array}{c}\text { Total } \\
\text { farmer } \\
\text { (inhabitant) }\end{array}$ & $\begin{array}{r}\text { Percentage } \\
(\%)\end{array}$ \\
\hline 1. & $0.80-0.84$ & 9 & 15 \\
2. & $0.85-0.89$ & 11 & 18,3333 \\
3. & $0.90-0.94$ & 13 & 21,6667 \\
4. & $0.95-0.99$ & 27 & 45 \\
\hline & Total & 60 & 100 \\
\hline
\end{tabular}

The data of Table 2 indicates that the number of the farmer having highest technical efficiency score, that is at the technical efficiency level of $0.95-0.99$ by $45 \%$ or 27 cassava farmers of the total respondents. Technical efficiency between $0.90-0.94$ results in 13 cassava farmers or amounting to $21.7 \%$. While the technical efficiency ranges from $0.85-0.89$ results in 11 cassava farmer or $8.70 \%$ and the range of efficiency level at $0.80-0.84$ finds 9 farmers or $15 \%$. According to this data, this means that farmer still has a chance up to $1-20 \%$ to increase cassava production. Different efficiency level among the farmer indicates the difference of production factors usage of each farmer.

In addition, the difference of efficiency can be caused by several factors, i.e. age, experience, formal education, nonformal education and total family member. The average technical efficiency of a farmer in the research area is not approaching 1 . This indicates that cassava farmer in the research area still has a chance to increase technical efficiency or actual production that is not approaching potential production yet. The average efficiency can be seen in Table 3 below.

According to Table 3., it concludes that the lowest cassava farming technical efficiency is 0.80 , which means that the respondent of this efficiency level is able to reach $80 \%$ potential of cassava production gained from the combination 
of production factors usage, i.e. land, seeds, labour, cost and animal manure in running cassava farming.

Table 3. Statistic Distribution of Cassava Farming Technical Efficiency at Bitefa Village in 2013

\begin{tabular}{llr}
\hline No & Statistic & Efficiency Level \\
\hline 1 & Minimum & 0,80 \\
2 & Maximum & 0,99 \\
3 & Average & 0,94 \\
\hline
\end{tabular}

This indicates that there is still a chance of about $20 \%$ for a farmer to increase cassava production using efficient production factors. For a while, the highest efficiency level is 0.99 . This also means that the farmer has reached $99 \%$ of cassava production potential gained from usage combination of production factors in the research area.

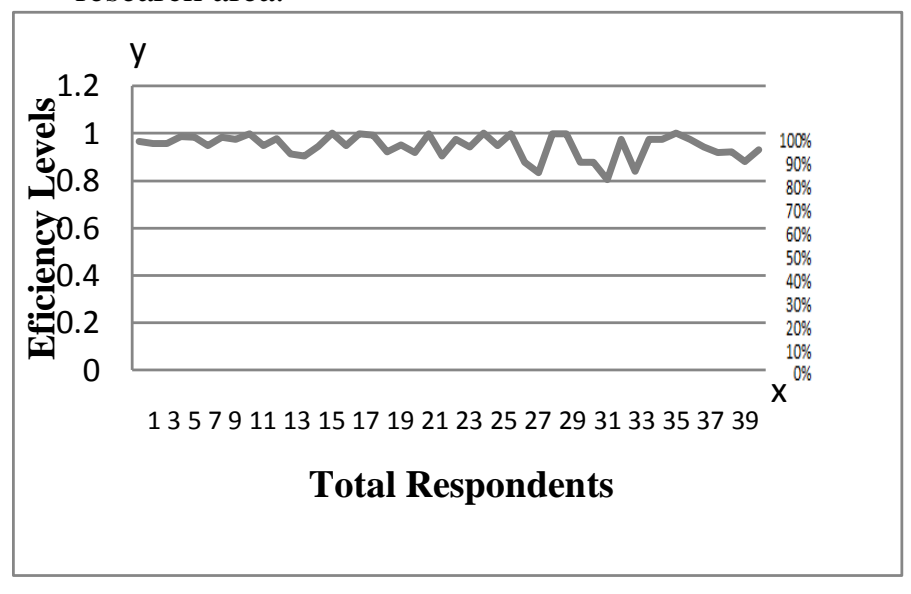

Figure 1. Technical Efficiency Spreading of Each Respondent

This estimation result also indicates that there is only $1 \%$ chance for a farmer to be able to increase his/her farming production to reach technical efficiency level. According to the average estimation, respondents have efficiency level that is still low by $0.94 \%$ which means on average the farmer just achieved production by $94 \%$ of the cassava production potential and there is still $6 \%$ remaining that needs to be achieved to increase his/her production to be able to reach efficiency or achieve potential production level. Graphically, technical efficiency rate for each respondent can be seen in figure 6 below;

The figure demonstrates that the average technical efficiency rate has reached up to $94 \%$, which means there is still a chance of $6 \%$ for a farmer to reach production efficiency, this indicates farmer's ability to manage his/her farming is not achieved production rate potentially yet. In order to increase cassava production efficiency, it needs to improve the ability in combining the existing production factors through training, socialization, and adoption of better innovation.

b. Allocative Efficiency Analysis of Cassava Farming

Allocative efficiency Analysis of production factor usage for cassava farming in the research area can be known by calculating NPM ratio of a production factor with each production factor price. Not all production factors for allocative efficiency was analyzed, it is only those having a significant influence on the cassava production. Factors having real influence over the cassava production in the research area using stochastic frontier approach and MLE methods are the land area and seed, thus, there are only those 2 factors that will be counted its allocative efficiency. Allocative efficiency calculation can be seen in Table 4 .

Table 4. Allocative Efficiency Analysis of Cassava Farming Production Factors Usage at Biteva Village in 2013

\begin{tabular}{llllllrc}
\hline Variable & Bix & Y & PY & X & Px & NPMx & NPMx/Px \\
\hline land area & 3,299 & 2709,32 & 3000 & 76,37 & 534590 & 3830,591434 & 0,0071655 \\
Seed & 2,266 & 2709,32 & 3000 & 19,09 & 38180 & 92,0897868 & 0,002412 \\
\hline
\end{tabular}

1) Land Area Usage Allocative Efficiency

According to the data of analysis result in table 4 , it is known that NPMx/Px of land area usage is 0.0071655 at which this number is smaller than 1 so that land area usage in the research area is in an allocative manner not efficient yet. This indicates that land usage in a 76,37 acre or 0.7637 ha at the research area is not efficient yet. This result also shows that even tough land area has a real influence on the production but in an allocative manner this is not efficient yet.

Not efficiency yet the use of the land area in an allocative way are caused by farmer's ability to manage farming that is still low. In addition, the production result is not only sold but also met the daily needs (subsystem). For that matter, in an allocative manner, land use can be 
said not efficient yet since someone is categorized efficient in an allocative way if getting profit from the business run (Soekartawi, 2002).

\section{2) Allocative Efficiency of Seed Usage}

The analysis result of table 4 shows that $\mathrm{NPMx} / \mathrm{Px}$ of seeds usage is 0.002412 at which this number is smaller than 1 so that the use of seeds is not efficient yet. This reveals that the use of seed amounting to $19,09 \mathrm{~kg} /$ is in the research area is not efficient yet.

Not efficiency yet the use of seed in allocative ways is caused by the real condition in the research area in which farmer's ability to manage his/her farming is still low and the cost allocated to buy seeds is also low. It influences by the local seed used or seed from the previous farming result by $\mathrm{Rp} 2,000,-/ \mathrm{kg}$, while the production result is not sold but just to be used to meet the needs (subsystem). Therefore, the use of seeds in allocative ways can be said not efficient yet since someone can achieve efficiency in an allocative way if getting profit from the business run (Soekartawi, 2002).

\subsection{Analysis of Factors Influencing Cassava Farming Inefficiency}

Factors put into the model of this research are farmer's age, farming experience, formal education, non-formal education and total dependents. The analysis result of inefficiency effect can be seen in Table 5 .

Table 5. Estimation Result of Factors Influencing Cassava Farming Inefficiency at Bitefa in 2013

\begin{tabular}{lrrr}
\hline \multirow{2}{*}{ Variable } & \multicolumn{3}{c}{ MLE (Maximum Likelihood } \\
& \multicolumn{3}{c}{ Estimation) } \\
\cline { 2 - 4 } & Coefficient & $\begin{array}{c}\text { Standard } \\
\text { error }\end{array}$ & t-ratio \\
\hline Intercept & 7.69 & 1.15 & 6.68 \\
\hline Intercept (X1) & -0.19 & 0.44 & -0.44 \\
\hline $\begin{array}{l}\text { Experience } \\
\text { (X2) }\end{array}$ & 0.12 & 0.21 & 0.58 \\
\hline
\end{tabular}

\begin{tabular}{lccc}
\hline $\begin{array}{l}\text { Formal } \\
\text { education } \\
(\mathrm{X} 3)\end{array}$ & -0.27 & 0.24 & $-1.09^{* * *}$ \\
\hline $\begin{array}{l}\text { Non-formal } \\
\text { education } \\
\text { (X4) }\end{array}$ & & & \\
\hline $\begin{array}{l}\text { Dependents } \\
\text { (X5) }\end{array}$ & 0.44 & 0.17 & $2.53^{* *}$ \\
\hline t-tabel $=2.021$ (significant at 5\% error) & \\
\hline t-tabel $=0.680$ (significant at 25\% error) & \\
\hline
\end{tabular}

Interpretation of each source of technical inefficiency is presented below.

a. Age

The coefficient value of farmer's age is negative by -0.19 and $\mathrm{t}$-count value is -0.44 . $\mathrm{t}$ count value is smaller than $t$ table by $0.44<0.68$ so that the factor of farmer's age has a negative but not significant influence over the technical inefficiency effect of cassava farming with $25 \%$ error level. This indicates that the older the farmer, the farther the possibility to achieve technical efficiency.

\section{b. Farming Experience}

Estimation result of table 5 indicates that experience has a positive value but not having significant influence over the technical inefficiency with 25\% error level. Experience variable coefficient by 0.12 with t count value smaller than $\mathrm{t}$ table by $0.58<0.68$ indicates that the increase of $1 \%$ will enhance technical efficiency by 0.12 , this is not in accordance with the previous expectation that is negative coefficient. Having a positive sign and not significant influence over the farmer's experience is caused by the practice of application of growth pattern and cassava farming that is still conducted in a traditional way.

\section{c. Formal Education}

The coefficient value of farmer's formal education factor has a negative sign by -0.27 and $\mathrm{t}$ count by 1,09 higher than $\mathrm{t}$ table that is $1.09>$ 0.68 , so that the factor of formal education of respondent even tough has a negative sign still has a significant influence on the technical effect of cassava farming with error level by $25 \%$. Formal education is measured based on the educational background posited cassava farmer to finish his/her study. This is in accordance with the hypothesis stating that formal education has a negative influence on the technical efficiency level.

\section{d. Nonformal Education}

The coefficient value of nonformal education factor is positive by 0.44 and $t$ count value is 2.53 that is higher than $t$ table by $2.53<$ 2.02 (t-table 5\%), thus, nonformal education is positive and has a significant influence over the technical inefficiency effect to manage cassava farming with $5 \%$ level of error. Nonformal education is measured based on the frequency of farmer's participation to join training and socialization. Having a positive value is in 
accordance with the research expectation. Average. A farmer in the research area follows nonformal education twice. Nonformal education has a significant influence on the inefficiency effect since the farmer is given information and understanding on farming not a common knowledge at formal education.

\section{e. Total family Numbers}

The coefficient value of total family member's sign is positive and its score is 0.02 while $t$ count is 0.22 . $\mathrm{T}$ count value is smaller than $\mathrm{t}$ table, that is $0.02<0.68$ so that the factor of a total family member has a positive but not significant influence over the technical inefficiency in cassava farming with $25 \%$ error level.

Research expectation is negative but the analysis result indicates a positive relationship. This indicates that the number of a family member does not have an influence on the inefficiency effect level. Having much more family member does not mean they exactly know how to manage cassava farming so it will not help farmer more.

\section{Conclusion}

The conclusions of the discussion above are ;

Factors having a significant influence on the production of cassava are a land area at the significant level of $1 \%$ and seed at $25 \%$ level. In addition to labor factor, costs and seeds have a not significant influence.

The lowest technical efficiency level of cassava in the research area is 0.80 while the highest is 0.99 . The farmer has averagely technical efficiency level by 0.94 which means the farmer has just reached production by 86 percent of the cassava production potential and there is still $6 \%$ left for average farmer to increase the production. NPMx/Pc is for land use and seed $<1$ so that land area usage is not efficient yet.

Factors influencing inefficiency effect are formal education has a negative influence since the formal one more discusses common knowledge not special on cassava farming. On the other hand, nonformal education has a positive influence which means if the farmer follows the training and socialization frequently will have a purpose to increase the technical efficiency of cassava farming since the knowledge gained from attending training and socialization is more directed to the application of farming culture.

\section{References}

Barber., \& Benedito de Barber. (1980). Faktorfaktor Budidaya Tanaman Pangan. Artikel Pertanian.

BPS Timor Tengah Utara. (2013). Kabupaten Timor Tengah Utara Dalam Angka 2012. Kefamenanu: Badan Pusat Statistik Kabupaten Timor Tengah Utara.

Coelli, T.J., D.S. Prasada. Rao, and G.E. Battese. (1998). An Introduction to Efficiency and Productivity Analysis. Kluwer Academic Publishers. Boston/Dordrecht/London.

Laporan Kinerja Kementrian Pertanian. (2011). Kementerian Pertanian Republik Indonesia 2012.

Makeham J. P dan Malcolm R. L. (1990). Manajemen Usahatani Daerah Tropis. Bogor.

Montagnac, J. A., Davis, C. R., \& Tanumihardjo, S. A. (2009). Nutritional value of cassava for use as a staple food and recent advances for improvement. Comprehensive reviews in food science and food safety, 8(3), 181-194.

Soekartawi. (2002); Teori Ekonomi Produksi, dengan pokok bahasan Fungsi Cobb Douglas. Rajawali Press. Jakarta. 